\title{
CHARACTERIZATION AND QUANTIFICATION OF PROTEINS IN WHEY OBTAINED AS A BY-PRODUCT FROM WHITE CHEESE AND YELLOW CHEESE PRODUCTION"
}

\author{
Aleksandar Chadikovski ${ }^{1}$, Tome Nestorovski ${ }^{2}$, Vesna Rafajlovska ${ }^{1}$, Macdonald Wick ${ }^{3}$, \\ Zoran T. Popovski ${ }^{1,2, *}$
}

\author{
${ }^{1}$ Department of Food Technology and Biotechnology, Faculty of Technology and Metallurgy, \\ Ss. Cyril and Methodius University, Skopje, Republic of Macedonia \\ ${ }^{2}$ Department for Biochemistry and Genetic Engineering, Faculty of Agricultural Sciences and Food, \\ Ss. Cyril and Methodius University, Skopje, Republic of Macedonia \\ ${ }^{3}$ Department of Animal Sciences, College of Food, Agricultural and Environmental Sciences, \\ Ohio State University, Columbus OH - USA \\ *e-mail: zoran_popovski@yahoo.com
}

\begin{abstract}
After the cheese production process, the whey, obtained as a by-product, is not valorised and remains in the waste water which is usually disposed of in natural watercourses. The aim of the study was to analyse the profile of whey proteins, as well as, to quantify the amount of those fractions. 12.5\% SDS-PAGE was used. The total amount of proteins in whey from cow white cheese was $0.73 \% \pm 0.15$, while in cow kashkaval whey was $0.91 \% \pm 0.08$. In whey from white cheese, the relative protein percentages were: lactoglobulin $67.29 \% \pm 4.99$, lactalbumin $20.64 \% \pm 2.02$ and other fractions related to bovine serum albumin with $12.07 \% \pm 3.05$. In whey from yellow cheese, the proteins percentages were: lactoglobulin 52.62\% $\% 1.21$, lactalbumin $17.62 \% \pm 1.26$ and other fractions related to bovine serum albumin with $29.74 \%$, respectively. Predominantly, $\beta$-lactoglobulin was present in the analysed samples. The valorisation of the waste whey obtained in the white cheese production, and development of new product also contributes in the environment protection.
\end{abstract}

Key words: whey proteins; protein profile; by-product

\section{INTRODUCTION}

Whey is a by-product in cheese manufacturing process, in general defined as the serum or watery part of milk that remains after the separation of the curd that forms as a result of the milk coagulation by acid or proteolytic enzymes. The whey composition depends on the type milk and cheese or the method of casein precitipation that the manufacturer has applied [1].

The whey protein fractions contains about $50 \%$ $\beta$-Lg, $25 \% \alpha$-La and $25 \%$ other protein fractions, including immunoglobulins. There are wide variations in composition depending on the milk supply, and the process involved in the production of the whey. Whey is classified into three groups: sweet whey $(\mathrm{pH}$ typically 5.8-6.6), medium acid whey (pH typically 5.0-5.8) and acid whey ( $\mathrm{pH}>5.0)$. In general, the whey obtained from rennet-coagulated cheese develops low levels of acidity, whereas the whey from fresh acid cheeses, such as Ricotta or Cottage cheese, yields medium acid or acid whey. The whey from caseins produced by acid is classed as high acid whey, whereas whey from rennet casein is sweet whey [2].

Whey proteins are well known for their high nutritional value and versatile functional properties in food products. The worldwide production estimation of whey indicate that about 700.000 tons of whey proteins are available as valuable food ingredients. The nutritional and functional characteristics of whey proteins are related to the structure 
and biological functions of these proteins [3]. Whey protein products, such as whey protein concentrate or whey protein isolate are widely used in the food industry due to the high functional and nutritive properties. Also, these products represent the best way for the utilization of whey proteins [4].

Another option for whey utilization is whey cheese production. Worldwide, the whey cheese types are manufactured according to traditional procedures by denaturation of whey proteins. Ricotta is the most important, and well-known, whey cheese in the world. The Macedonian type of whey cheese recognised as urda is produced from whey originating from kashkaval production [5].

The aim of this study was to compare protein profiles of different types of whey in relation to develop possible technology for the whey cheese obtained from white cheese. The knowledge of the protein profile of the whey derived from white and yellow cheese production will contribute in the development of procedures for valorization of the waste whey from white cheese production process.

\section{EXPERIMENTAL SECTION}

The samples of the whey obtained at the white brined cow cheese and yellow hard cow cheese production were analysed. White cheese production process is a vat technology with pasteurized milk at $79{ }^{\circ} \mathrm{C}$, whereas yellow cheese technology is a tank process with pasteurised milk at $72{ }^{\circ} \mathrm{C}$. Due to the different types of technologies, vats vs. tank, the yields of the final product were different. The yield obtained at white brine cheese production was $5.5 \mathrm{~L} \mathrm{milk} / \mathrm{kg}$ product, while at yellow hard cheese $9.8 \mathrm{~L}$ milk/kg product. The $\mathrm{pH}$ value of cheese whey and yellow cheese whey was 5.89 and 6.37, respectively. The total number of analysed samples was 6 in 4 repetitions.

Electrophoretic analyses were done using sodium dodecyl sulphate polyacrylamide gel electrophoresis (SDS-PAGE). The samples were analysed using $12.5 \% \mathrm{~T}$ resolving gels and were previously treated with equal amount of reducing buffer $(8 \mathrm{M}$ urea/2 M thiourea, $75 \mathrm{mM}$ DTT, $50 \mathrm{mM}$ Tris, $3 \%$ SDS, and $0.004 \%$ bromophenol blue, pH 6.8) [6].

The gel used for electrophoresis was divided into an upper $3 \% \mathrm{~T}$ stacking gel $\mathrm{pH}$ 6.8. The stacking gel has a role to deposit the proteins at the top of the resolving gel as a narrow band. SDS-PAGE was performed according to Laemmli method [7]. Briefly, samples were loaded onto a $12 \mathrm{~cm} \times 10 \mathrm{~cm} \times 1 \mathrm{~mm}$ polyacrylamide running gel consisting of a $12.5 \%$ resolving gel [30:0.8, acrylamide/ ( $\mathrm{N}, \mathrm{N}^{\prime}$-methylene bis-acrylamide)] and a $3 \%$ stacking gel containing 1 $\%$ SDS. Milk protein standards containing bovine casein (ap. $22 \mathrm{kDa}$ ), lactalbumin (ap. $14.5 \mathrm{kDa}$ ) and lactoglobulin (ap. $18 \mathrm{kDa}$ ) and bovine serum albumin (ap. 66,5 kDa) prepared as mixture in concentration of $20 \mathrm{mg} / \mathrm{ml}$. Electrophoretic separation was carried out at a constant voltage of $10 \mathrm{~V} / \mathrm{cm}^{1}$. Gels were stained with Coomassie Brilliant Blue G-250 and distained with $10 \%$ acetic acid. The analysis of the gels was done with Phoretix software (Nonlinear Dynamics New Castle on Tyne, UK) [8].

Photometric quantification of total proteins was performed in order to determine the residues of proteins in waste water after the cheese-making process using Bradford method [9].

\section{RESULTS AND DISCUSSION}

Utilization of the remaining proteins in whey waste water after the cheese-making process was the topic of this study with two objectives. The first one was to protect the natural water streams from pollution, and the second was to recycle the valuable remaining compounds to develop a new by-product. For such purposes were estimated the profile of the protein residues in whey waste water and their quantity.

The method of choice for protein profiling was SDS-PAGE. The type of electrophoresis used was of the denaturing type because it used dithiothreitol (DTT) that reduces all the disulphide bonds, while the sodium dodecyl sulphate bonds to all the protein regions, breaking all the non-covalent bonds and gives the proteins a negative charge. The optimization of conditions for SDS-PAGE electrophoresis on milk proteins from whey waste was done changing the voltage, duration and amount of applied sample. We found that the most conclusive results are reached using 12,5\% SDS-PAGE (Figure 1).

To confirm reproducibility of the electropherograms, two gels were prepared with 2 different sample concentrations, a stock and 1:1 dilution of the stock which were run under the same conditions (Figure 2).

The results showed that in all samples $\beta$ lactoglobulin was present in the highest concentration, followed by $\alpha$-lactalbumin and ending with fractions with the similar molecular weight as bovine serum albumin. Densitometric quantification of each fraction confirmed the visual observation. (Figure 3). 


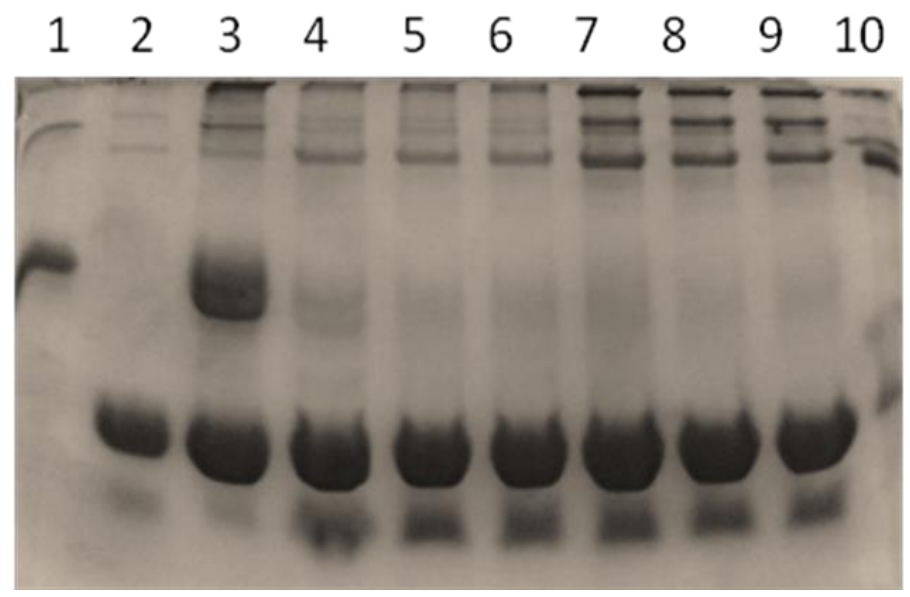

Figure 1. 12,5 \% SDS-PAGE on milk proteins: \#1 casein (standard), \#2 lactoglobulin (standard), \#3 milk protein mix (casein, lactoglobulin, bovine serum albumin - standards), \#4-6 three whey samples after production of cow white brine cow cheese, \#7-9 three whey samples after production of yellow hard cheese, \#10 BSA (standard)
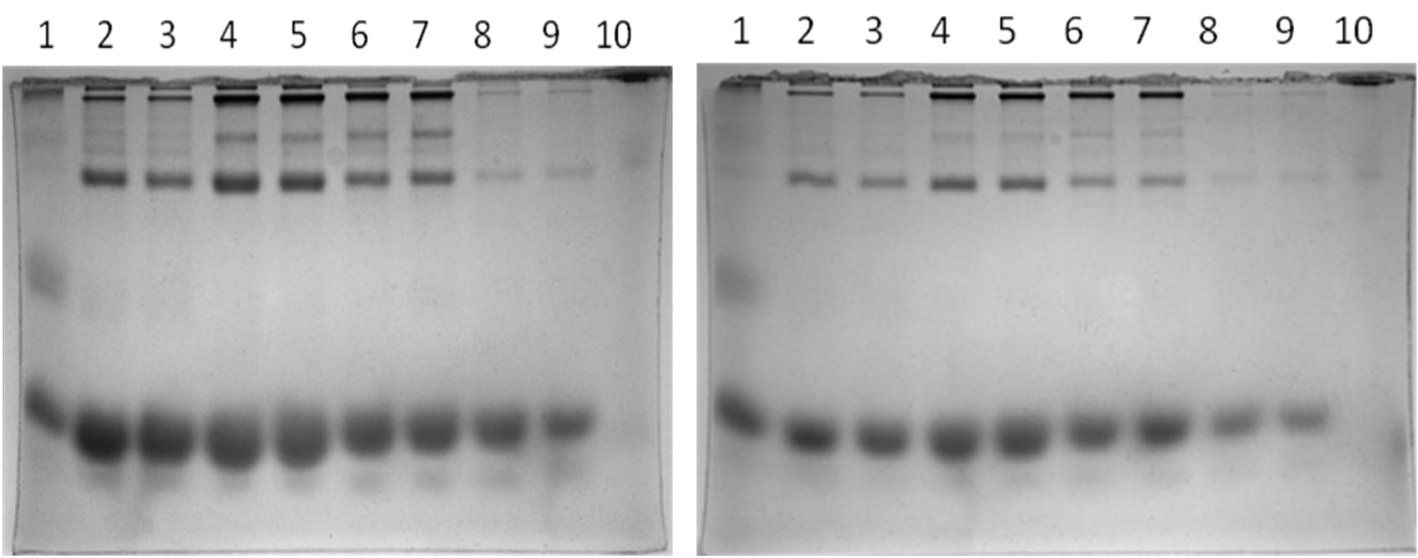

Figure 2. SDS-PAGE electroforegrams of the same samples with different dilutions. \#1 mix (casein,

$\beta$-lactoglobulin, $\alpha$-lactoalbumin ,BSA) \#2-3 whey from sheep white cheese ; \#4-5 whey from sheep yellow cheese; \#6-7 whey from mixed sheep-cow yellow cheese; \#8-9 whey from mixed sheep-cow white cheese; \#10 BSA standard.

A) Undiluted samples. B) Diluted samples $2 \times$

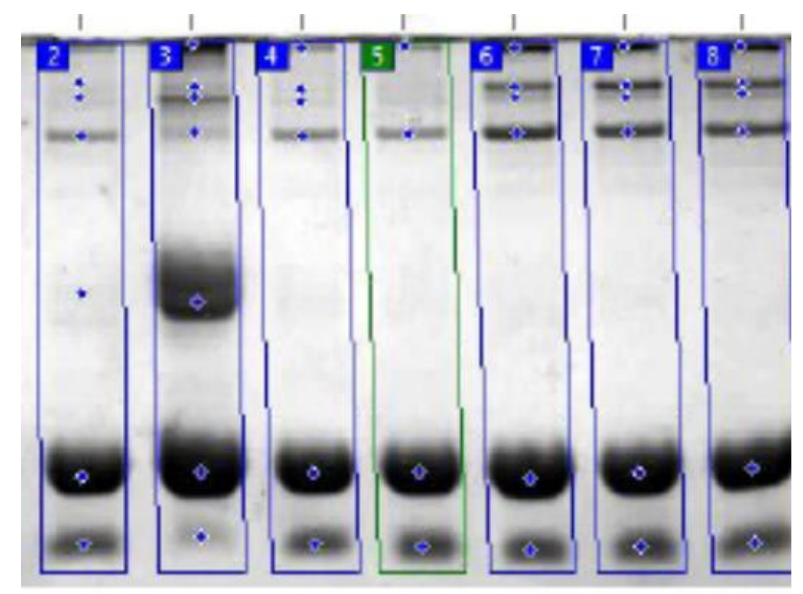

Figure 3. Phoretix analysis of $12.5 \%$ SDS-PAGE on separate fraction in protein profile:

\#2,4,5 Waste whey from white cheese; \#6-8 Waste whey from yellow cheese; \#3 Milk protein standard. 
Numerical data on percentage participation of each fraction are shown in Graph 1 and 2. Because we didn't have precise distinction between the fractions with molecular weight close to BSA, we labeled those fractions a BSA 1, 2, 3 and 4 .

After cheese processing, the total amount of proteins in the whey waste water from white cheese was $0.71 \% \pm 0.15$, while it was $0.91 \%+0.8$ in the waste water after yellow cheese production (Graph. 3).

The results showed that the quantity and composition of proteins in whey waste water after the production of white and yellow cheese are stable and is a good basis for recycling of those proteins in development of new products. Future product development should be turned in the direction of valorisation of the white cheese whey waste for whey cheese production. Knowledge of whey composition and adjustments of the process parameters in whey cheese technology could allow manufacturing of whey cheese to realize maximal yield. Also, white cheese whey could be the basic raw material for the production of traditional lactose free whey cheese $[10,11]$. Usage of waste whey in some products will contribute in improvement of physicochemical parameters $(\mathrm{COD}, \mathrm{BOD}, \mathrm{pH})$ of waste water and environmental protection [12].

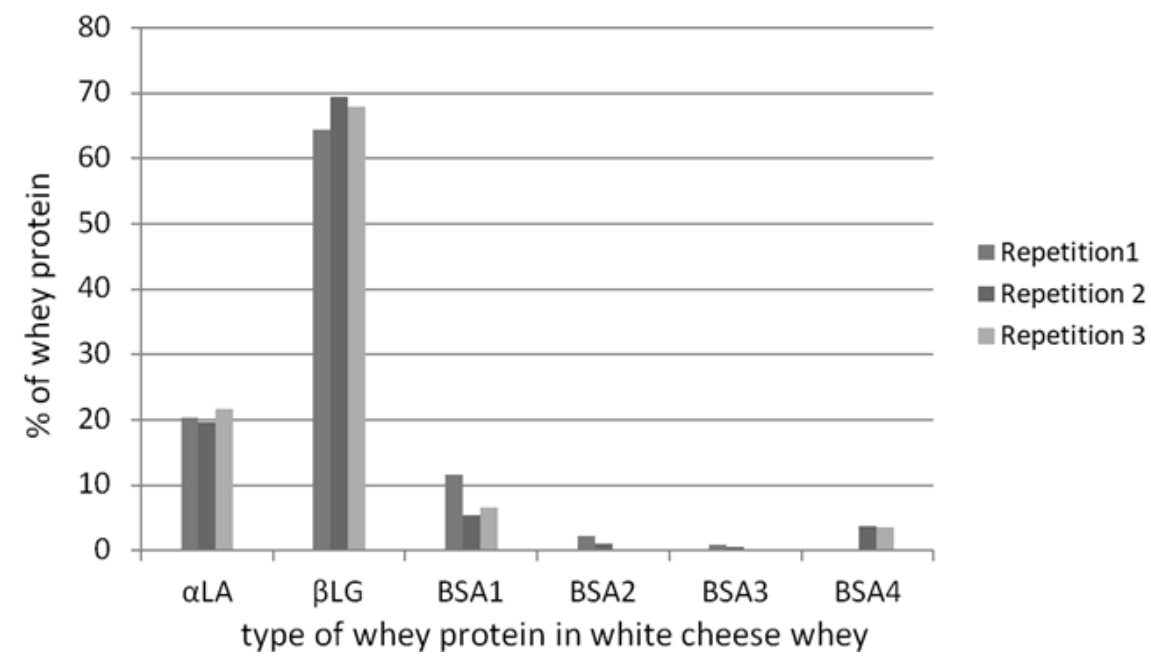

Graph 1. Percentage of each fraction in whey waste water after white cheese making process in three repetitions

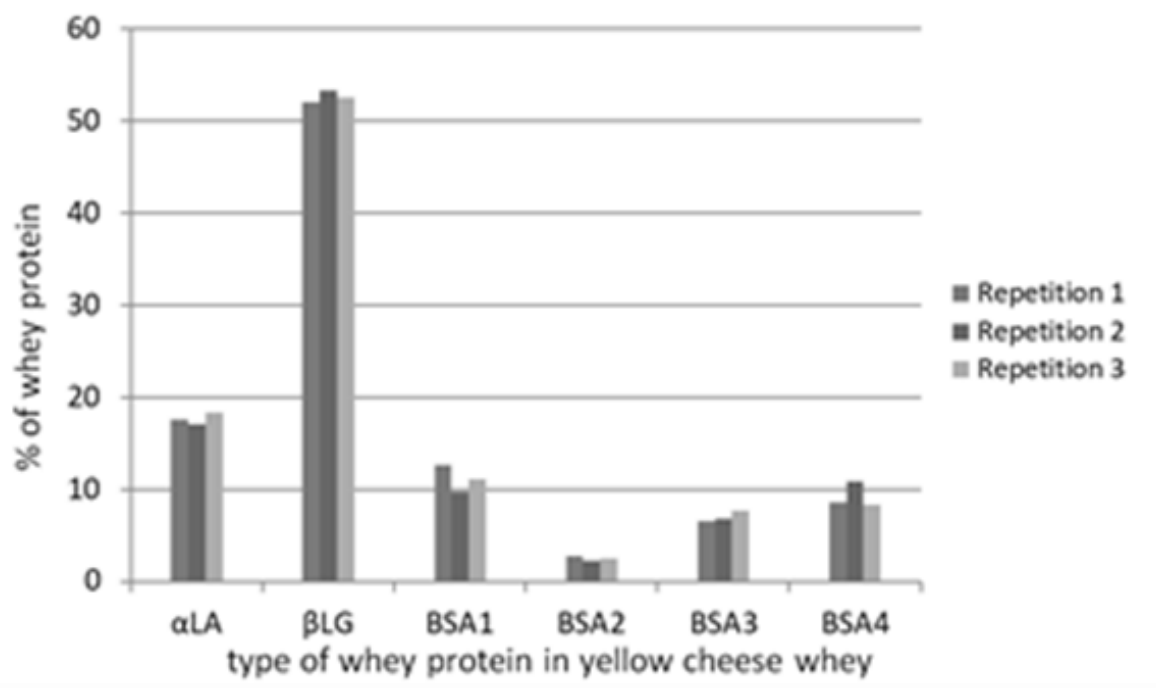

Graph 2. Percentage of each fraction in whey waste water after yellow cheese making process in three repetitions 


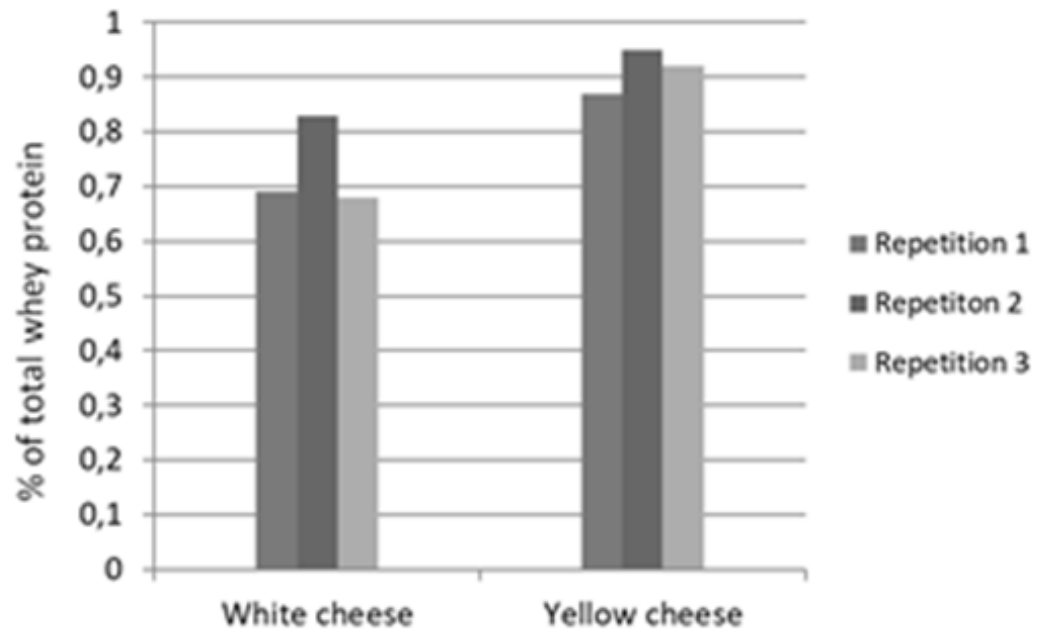

Graph 3. The amount of total protein in whey waste water after white and yellow cheese making process

\section{REFERENCES}

[1] A. Thompson, M. Boland, H. Singh, Milk Proteins: from Expression to Food, Elsevier Inc., New York, 2009, pp. 163-190.

[2] R. K. Robinson, Modern Dairy Technology, Volume 1 Advances in Milk Processing Second Edition, Springer Science+Business Media, Dordrecht, 1994, pp. 313-374.

[3] A. Bhati, K. H. Khan, Whey protein and its application to human, Journal of Experimental Sciences, 1, 1 (2010), pp. 16-20.

[4] S. Jovanović, M. B. Barac, Whey proteinsProperties and Possibility of Application, Mljekarstvo, 55, 3 (2005), pp. 215-233.

[5] M. E. Pintado, A. C. Macedol, F. X. Malcatal, Review: Technology, Chemistry and Microbiology of Whey, Food Science and Technology International, 7 (2001), pp. 105-116.

[6] Popovski Z. T., Wick M., Eastridge M., Gjorgjievski S., Nestorovski T., Svetozarevic M.: Influence of gossypol on electrophoretic mobility of milk proteins in dairy cows exposed to cottonseed diet, International symposium of animal sciences, Belgrade 2016, Proceedings, pp. 186-195.
[7] U. K. Laemmli: "Cleavage of structural proteins during the assembly of the head of bacteriophage T4", Nature, 227 (5259), (1970), pp. 680-685.

[8] Svetozarevic M., Nestorovski T., Popovski Z. T.: Electrophoretic distinction of the origin in different dairy products and milk samples, International symposium on animal sciences, Belgrad, Serbia, September 23-25, 2014. Proceedings of papers. pp. $551-557$

[9] M. M. Bradford, Rapid and sensitive method for the quantitation of microgram quantities of protein utilizing the principle of protein-dye binding, Anal. Biochem., 72 (1976), pp. 248-254.

[10] L. Pulinas, C. Spanu, G. Nieddu, S. Virdis, C. Scarano, F. Piras, N. Spano, G. Sanna, E. De Santis, Production of farmstead lactose-free Pecorino di Osilo and ricotta cheeses from sheep's milk; Italian Journal of Food Safety, 6, 6353 (2017), pp. 33-39

[11] P. Walstra, J. T. M. Wouters, T. J. Geurts, Dairy Science and Technology, CRC Press Taylor \& Francis group, 2006, pp. 542

[12] Britz T., Robinson R. K., Advanced Dairy Science and Technology, Wiley-Blackwell, 2008, pp. 1-28. 


\title{
КАРАКТЕРИЗАЦИЈА И КВАНТИФИКАЦИЈА НА ПРОТЕИНИТЕ ВО СУРУТКА КАКО НУСПРОИЗВОД ОД ПРОИЗВОДСТВОТО НА СИРЕЊЕ И КАШКАВАЛ
}

\author{
Александар Чадиковски ${ }^{1}$, Томе Несторовски ${ }^{2}$, Весна Рафајловска $^{1}$, Macdonald Wick $^{3}$, \\ Зоран Т. Поповски ${ }^{1,2^{*}}$ \\ ${ }^{1}$ Оддел за Прехранбена технологија и биотехнологија, Технолошко-металуршки факултет, \\ Универзитет „Св. Кирил и Методиј“, Скопје, Република Македонија \\ ${ }^{2}$ Оддел за биохемија и генетско инженерство, Факултет за земјоделски науки и храна, \\ Универзитет „Св. Кирил и Методиј“, Скопје, Република Македонија \\ ${ }^{3}$ Department of Animal Sciences, College of Food, Agricultural and Environmental Sciences, \\ Ohio State University, Columbus OH - USA
}

Сурутката добиена како нус-производ од производството на бело сирење, не се валоризира во индустријата за млечни производи и директно оди како отпадна вода. Целта на ова истражување беше да се утврди протеинискиот профил на сурутката, а воедно и да се квантифицира количеството на одделни фракции. $12,5 \%$ SDS-PAGE беше корисен како стандард за електрофоретската техника. Вкупното количество на протеини во сурутка од бело кравјо саламурено сирење е $0,73 \% \pm 0,15$, додека во сурутка од кравји кашкавал е 0,91 $\pm 0,08$. Кај сурутката од белото сирење, одделните фракции се застапени со следниве проценти: $67,29 \% \pm$ 4,99 лактоглобулин, $20,64 \% \pm 2,02$ лактоалбумин и $12,06 \% \pm 3,05$ говедски серум албумини. Во сурутката од кашкавал, суруткините протеини се присутни со следниве проценти: 52,62\% $\pm 1,21$ лактоглобулин, 17,62 $\pm 1,26$ лактоалбумин, и 29,74 \% говедски серум албумини. Во анализираните примероци на сурутка е утврдено дека доминира $\beta$-лактоглобулинот. Валоризацијата на отпадната сурутка од производство на бело сирење во развој на нов производ придонесува во заштитата на животната средина.

Клучни зборови: суруткини протеини; протеински профил; нус-производ 